Editorial

www.mdpi.com/journal/laws/

\title{
Double Blind Peer-Review in Laws
}

\author{
Frank Pasquale ${ }^{1}$ and Martyn Rittman ${ }^{2}$
}

1 Francis King Carey School of Law, University of Maryland, 500 W. Baltimore Street, Baltimore, MD 21201-1786, USA; E-Mail: fpasquale@law.umaryland.edu

2 MDPI AG, Klybeckstrasse 64, CH-4057 Basel, Switzerland; E-Mail: rittman@mdpi.com

Received: 8 October 2015; Published: 10 October 2015

We are pleased to announce that all manuscripts submitted to Laws after 10 October 2015 will be reviewed using a double blind peer-review process. This means that, in addition to authors not knowing the identities of reviewers, during the review process reviewers will not know the identities of the article's authors. This process has become standard in the field and we are pleased to respond to the feedback of scholars wishing to publish in the journal.

Our sincere hope is that the change to double blind peer-review will give a more balanced review, with feedback less likely to suffer from unconscious bias and reviewers able to focus solely on the work in hand. We also believe that this process will benefit scholars without an established reputation.

The standard of peer-review in Laws has been excellent and we would like to take this opportunity to thank the many reviewers who have participated, along with the Editorial Board and other academic editors who have assisted in overseeing the editorial process. We hope that this step will serve to further improve the standard of Laws.

\section{Conflicts of Interest}

The authors declare no conflict of interest.

(C) 2015 by the authors; licensee MDPI, Basel, Switzerland. This article is an open access article distributed under the terms and conditions of the Creative Commons Attribution license (http://creativecommons.org/licenses/by/4.0/). 